\title{
Byråkrati och personligt bemötande - studier av tidsbeställning
}

\author{
LEILA BILLQUIST
}

\begin{abstract}
När det gäller ansökan om ekonomisk hjälp sker människors första kontakt med socialbyrän oftast via telefon. Artikeln lyfter fram dessa initiala samtals betydelse för klienten och för vägen in i ett klientskap och visar på ett första samtal där den sökande och dennes problem inte bara behöver reduceras till att passas in i organisationens administrativa kategorier.
\end{abstract}

\begin{abstract}
"Tidsbeställningen, (namn) ... ja, hej ... ja ... nu har du flyttat hit ... jaså ... så nu bor du här, var bor $d u$ då? ... kan jag få ditt personnummer? (knappar in på datorn för att kolla namn och framför allt adress) ... du står fortfarande skriven här ... (skrattar) $i$ dag är det måndag ... separerat frän sambo, ni var inte gifta? (skriver ner uppgifter på särskild blankett; nybesök checklista och statistik) ... sålde, vilken datum var det $d u$ sa? ... jobbar $d u$ ? ... arbetslös ... inga inkomster och ändå fick du lägenhet ... kallas duför Sofia ${ }^{1}$ ?.. du har inte telefon? ... det har du, vilket nummer? ... tillbaka till rötterna ... nu är det så att vi har första lediga tid den 5 februari
\end{abstract}

Leila Billquist, socionom, fil.mag. i socialt arbete, universitetsadjunkt och doktorand vid institutionen för socialt arbete, Göteborgs universitet. Utöver pågående avhandlingsarbete om det sociala arbetets innehåll och utförande inom dagens individoch familjeomsorg medverkar hon i ett forskningsprojekt kring systemförändring och människobehandling. (sedan förklarar socialsekreteraren att sökande bör ta kontakt med hyresvärden och berätta att hon varit i kontakt med socialbyrån men att hon fått tid först till den 5 februari och hon kan också be om att få anstånd med hyran tills dess. Besked lämnas också om vilken socialsekreterare sökande fätt tid hos) ... då fär du vänta en vecka till ... men det hinner $d u$... dä är $d u$ välkommen då och jag skickar hem informationsbroschyr och ansökan " (citat från observation av tidsbeställning vid ett socialkontor i Göteborg).

1 Samtliga namn angivna i citat är fingerade. Direkta citat från intervjuerna (klient-) eller från observationerna av tidsbeställningssamtalen har i texten angivits med citationstecken och skrivits i kursiv stil. Citat från intervju/uppföljande samtal med socialsekreteraren i tidsbeställningen har i löpande text endast angetts med citationstecken för att särskilja dem från observationscitaten. 
Om allmänheten vill komma i kontakt med socialtjänsten och ta del av dess tjänster är det vanligaste sättet att ringa antingen för att få information eller för att beställa tid för ett personligt möte. Oftast är detta tillvägagångssättet förekommande då det gäller ansökan om ekonomisk hjälp. På varje socialkontor har man fastställda telefontider då det är möjligt för människor att ringa för att höra sig för eller beställa tid för ansökan om ekonomisk hjälp. Hur denna telefonmottagning är organiserad kan variera från socialkontor till socialkontor. På en del kontor har varje socialsekreterare en daglig telefontid om en timma och tar emot tidsbeställning av "nybesöku, dvs. från personer som aldrig tidigare eller som inte på två eller tre månader haft någon kontakt med socialkontoret. Dessa samtal fördelas efter vilken dag i månaden den sökande är född eller om den sökande är gift eller sambo efter vilken dag mannen är född. På andra kontor har man en särskild person, oftast en socialsekreterare, eller flera som enligt ett rullande schema ansvarar för tidsbeställningen vilken sker på fastställda dagar och tider. Man kan också ha speciella mottagningsgrupper. Den första kontakten sker alltså oftast via telefonsamtal. Vad händer $i$ detta samtal? Hur upplever de som kontaktar socialkontoret denna första kontakt? Hur ser de på samtalet och bemötandet? Vilken betydelse har detta första samtal för vägen in iett klientskap?

\section{Tidigare forskning}

Det finns en hel del studier som behandlar människors möten med olika myndigheter eller offentliga organisationer och vad som händer med människor i dessa möten. En del av dessa studier bygger på samtalsanalys där språkliga och kommunikativa mönster stått i fokus (se t.ex. Erickson/ Shultz 1982, Wahlen/Zimmerman/Whalen 1988). Andra forskare pekar på de kontextuella sammanhangen, inte minst platsen där samtalet äger rum, som centrala för en mer fullständig förståelse och förklaring till vad som händer i samtalet (Linell 1990, Bernler/Johnsson 1995). En tredje grupp sätter mötena/samtalen i relation till samhället och dess utveckling (Sarangi/ Slembrouck 1996). Det finns också forskning som tagit sin utgångspunkt från de organisationer inom vilka mötena ägt rum. En forskning som konstaterar att människor i sin kontakt med en byråkratisk organisation "...egentligen inte längre är en människa utan blir ett fall" (Ahrne 1987 s 196) och där man studerar hur denna transformationsprocess, som benämns people-processing, går till (Prottas 1979, Lipsky 1980, Johansson 1992). Studier, med olika teoretiska utgångspunkter, finns också över hur det personliga mötet mellan socialsekreterare och klient utformas och upplevs (Marklund/Nordenstam/Penton 1984, Ranger 1986, Hydén 1988, Nilsson 1989, Fredin 1993, Cullberg 1994, Bernler/Johnsson 1995) medan det däremot finns färre studier över det inledande tidsbeställningssamtalet och dess betydelse för ett fortsatt klientskap.

Om vi vill skapa oss en uppfattning om hur de personer som ringer till socialbyrån slussas vidare i organisationen eller få en bild av "hur kedjan av kontakter mellan klienter och socialförvaltningens tjänstemän förlöper", som Elisabet Cedersund säger i sin studie "Från personligt problem till ad- 
ministrativt beslut. Att ansöka om ekonomiskt bistånd (1992 s 16), måste även detta inledande samtal ingå i en analys för det är här som en första sortering görs av vem som går vidare i organisationen eller inte. En första etikettering och kategorisering sker av den sökande och dennes problem. Här startar den process som innebär att den sökande genom kontakt med myndighetens tjänstemän omvandlas till klient och de personliga problemen transformeras om för att passa organisationens administrativa kategorier. Omvandlingen av individer till fall eller ärenden påbörjas (jfr Prottas 1979, Lipsky 1980, Johansson 1992).

Cedersunds studie visar hur mötet mellan den biståndssökande personen och socialtjänstens anställda är utformat. Cedersund har genom, vad hon benämner deltagande observationer, följt klienter från första samtalet fram tills ett (första) beslut om ekonomiskt bistånd fattats. ${ }^{2}$ Sina såväl teoretiska som metodologiska utgångspunkter har hon tagit från både samtalsanalytisk-

2 Cedersund har i sin studie närvarit vid de initiala telefonsamtalen hos några av de socialsekreterare som mottagit samtalen angảende tidsbeställning. Hon har lyssnat till samtalen genom att ha hörlurar kopplade till telefonen (materialet har inte använts förrän klienten givit sitt samtycke) och hon har fört minnesanteckningar. Vid klienternas besök hos socialsekreterarna har antingen ljudbandinspelning av samtalen skett och i dessa fall har forskaren inte personligen närvarit eller som vid ett socialkontor har observationer gjorts. I min mening är detta inte att betrakta som deltagande observation, se vidare Henriksson och Månsson „Deltagande observation « (1996). Cedersund har också intervjuat socialsekreterare och klienter efter det besökssamtalen ägt rum, ej i direkt anslutning till gjord tidsbeställning. och byråkratiforskningstraditionen. Hennes studie visar på hur den enskilda människans problem och bekymmer förs över till organisationens terminologi och begreppsvärld.

Cedersund beskriver, när det gäller det initiala telefonsamtalet, samtalets uppläggning och innehåll samt analyserar dess funktion i bearbetningen av de sökandes problem. Hon menar att telefonsamtalet kan delas in i olika samtalsfaser relaterat till ämne, innehåll och parternas kommunikativa uppgifter. Telefonsamtalet har följande struktur; en inledning där presentation och hälsning äger rum. Därefter sker en ärendepresentation där den fråga eller begäran som är anledning till telefonsamtalet presenteras. I denna fas ligger oftast ansvaret på den som ringt upp. Samtalet går över i en utredningsfas där socialsekreteraren har ansvaret. Frågor om yrkesarbete, inkomster, utgifter, familjeförhållanden ställs. När utredningen är gjord följer förslag om åtgärd som i de flesta fall mynnar ut i tid för besök samt att en ansökningsblankett skickas hem till den sökande. Först i detta skede tas personuppgifter och därefter avslutas samtalet med t.ex. en påminnelse inför besöket och en avslutande hälsning. Personerna som möts i telefonsamtalen är reducerade till att vara klient och tjänsteman och deras respektive uppgifter är definierade till vad som är brukligt i denna typ av myndighetssamtal.

\section{Syfte och metod}

Genom att belysa vad som händer under det första samtalet med socialkontoret vill jag visa att den enskilde sökande och dennes 
problem inte bara behöver reduceras till att passas in $i$ organisationens administrativa kategorier. Jag kommer att granska samtalets innehåll och funktion, klienternas upplevelse av samtalet samt dess betydelse för vägen in i ett klientskap. Studiet över vad som händer vid det initiala telefonsamtalet eller vid tidsbeställningen ingår som en del av en större studie - Vad händer på socialbyrån? Det sociala arbetets innehäll och utförande inom dagens individ- och familjeomsorg, vars syfte är att studera hur klientsortering och -hantering sker och vilken betydelse detta har för formandet av ett klientskap. ${ }^{3}$ Detta påverkas av många olika faktorer, såväl organisatoriska som personella (Bernler m.fl. 1989). Klientskapet formas och utvecklas i den process som utspelar sig mellan socialsekreterare och klient. Det är en process som startar i och med det första samtalet och som inte enbart påverkas av organisationens rent byråkratiska faktorer utan där även andra faktorer, inte minst personella, spelar en roll. Genom att följa klienter under ett års tid via observationer och intervjuer, genom att följa dem från "första rösten", dvs. "vägen in och genom systemet«, vill jag studera vad som händer, var klienten hamnar, vad som styr, vilket handlingsutrymme såväl socialsekreterare som klient har, vilken hjälp klienten får och hur kontakten och hjälpen upplevs. ${ }^{4}$ Huvudstudien omfattar två socialkontor i Göteborg.

3 Hantering har jag gett en vidare definition än enbart administrativa handläggningsrutiner. I begreppet ingår också det behandlande arbetet, dvs. vilken hiälp och på vilket sätt klienten får hjälp.

4 Socialkontoren är idag oftast organiserade efter
För att studera vad som händer vid den första kontakten och hur denna "första röst" upplevs har jag, under min vistelse på båda socialkontoren, genomfört intervjuer och samtal med socialsekreterare och klienter. Den aktuella studien har genomförts på ett av socialkontoren och jag har där närvarit vid 18 tidsbeställningstillfällen hos den socialsekreterare som ansvarar för denna samt gjort fördjupade intervjuer med tolv klienter. ${ }^{5}$ Därutöver baserar sig min studie på statistik som förts i tidsbeställningen över antal och typ av samtal.

Jag har alltså för det första observerat hur socialsekreteraren hanterar samtalen i tidsbeställningen. Tolv gånger har jag suttit med under hela tidsbeställningen och vid de övriga sex gångerna endast del av telefontiden. Sammanlagt under dessa tidsbeställningstillfällen inkom 114 telefonsamtal. ${ }^{6}$ Dessutom skedde tidsbeställning genom person-

funktionsprincipen vilket innebär att man har grupper specialiserade på allmänt bistånd/ekonomi och specialiserade behandlingsgrupper: missbruk/vuxengrupp, barn- och familjegrupp m.m. Den första kontakten med dessa grupper kan ske på andra sätt än via telefonsamtal t.ex. via anmälningar från andra myndigheter eller anhöriga, vilket kommer att belysas i annat sammanhang.

5 Dessa tolv personer utgör en delpopulation $\mathrm{i}$ min totala undersökning. Även i samband med intervjuer med andra klienter t.ex. i samband med nybesök eller återbesök har frågor ställts kring hur kontakt tagits och tidsbeställningen upplevts som gett mig en «allmän« bild av uppfattningen om tidsbeställningen. På motsvarande sätt har jag vid mina samtal och intervjuer med socialsekreterarna (8) i ekonomigruppen erhållit deras uppfattning om tidsbeställningen.

6 Fler telefonsamtal (22) ägde rum, men dessa ingår ej i min studie då de var relaterade till andra uppgifter som socialsekreteraren har. 
ligt besök av fyra personer. Jag har fört anteckningar under samtalen och i så stor utsträckning som möjligt ordagrant återgivit socialsekreterarens frågor och kommentarer. Någon bandinspelning av samtalen har inte förekommit då min avsikt inte varit att studera interaktionen eller »...skildra de språkliga mikroprocesserna" (Cedersund 1992 s 11). Fokus för studien har snarare varit innehållet i dessa första samtal. I mån av tid efter telefonsamtalet har socialsekreteraren givit mig kompletterande information om samtalets innehåll samt sin uppfattning av samtalet och om tidsbeställningen som sådan. Jag har inte använt mig av hörlurar kopplade till telefonledningen. Jag har alltså inte lyssnat till den sökandes del av samtalet. Skälet att inte använda hörlurar har framför allt varit av etisk karaktär.

För det andra har tolv personer som ringt vid något av mina senare observationstillfällen och erhållit tid för nybesök, som alltså har slussats vidare in i organisationen, intervjuats för att ge sin bild och upplevelse av tidsbeställningssamtalet. ${ }^{7}$ Efter att jag hade deltagit under tidsbeställningen vid ett antal tillfällen och därmed bildat mig en uppfattning om samtalets uppläggning och struktur kontaktades per telefon ett slumpmässigt urval av elva personer. Det var personer som hade telefon och som var anträffbara inom en till två dagar efter den gjorda tidsbeställningen. Med tio av de tolv personer som har intervjuats, gjordes intervjun

7 Det hade varit intressant att även intervjuat de personer som "sorteras bort" vid tidsbeställningen, dvs. de som hänvisas till annan myndighet eller som avvisas, för att fått deras bild, men $i$ tidsbeställningen tas (oftast) inga personuppgifter avseende dem. direkt i samband med min uppringning. En person har intervjuats på socialkontoret eftersom tidsbeställningen skedde vid ett personligt besök på kontoret, vilket är ovanligt, och en person har efter önskan intervjuats i sin bostad. Intervjuerna är omedelbart nedskrivna. När det gäller de tolv intervjuerna finns således tre "bilder" att tillgå av tidsbeställningssamtalet; den intervjuades, socialsekreterarens och min egen bild. De intervjuade fördelar sig i ålder mellan 19-70 år. I populationen finns ensamstående män (3) och kvinnor (5), ensamstående kvinnor med barn (2), gifta (2) och också personer med utländsk härkomst (4). Fyra personer uppger att de tidigare inte haft någon kontakt med någon socialbyrå. De intervjuade utgör ett "tvärsnittı av gruppen socialbidragstagare (jfr Salonen 1993).

\section{Tidsbeställning - procedur}

Tidsbeställning kan göras tre förmiddagar per vecka och omfattar totalt 7,5 timmar. När man ringer kommer man först till stadsdelsförvaltningens telefonväxel. Där frågas efter vad ärendet gäller och oftast begär den sökande att få komma till socialkontoret eller till socialservice, som en av mina intervjuade uppgav att hon hade sagt. Den som ringer tillfrågas om adress, då det finns två socialkontor inom stadsdelsförvaltningens område, och om man är ett "förstagångsbesöku. Har man redan en kontakt på socialbyrån uppmanas man att ringa under dennas telefontid. Samtalet kopplas därefter till tidsbeställningen vid „rätt» kontor.

Antalet personer som ringer under en tidsbeställning kan variera kraftigt från 
bara ett par personer upp till 16-17. Det kan vara ett intensivt arbete för socialsekreteraren som under samtalet skall göra personkontroll på datorn, kortfattade anteckningar om vad ansökan gäller på en speciellt utformad blankett och också fylla i en informationsbroschyr till den sökande med bl. a uppgifter om vad denne skall ta med sig till nybesöket. ${ }^{8}$ Det ena samtalet kan direkt följas av nästa. Ibland får socialsekreteraren be den som ringer vänta medan han avslutar den "administrativa" delen av föregående samtal.

Samtalen kan variera till både innehåll, längd och uppläggning. Under mina observationer varade ett av de kortaste samtalen 3 minuter och ett av de längre 13 minuter. Statistik som förts av socialsekreteraren och mina egna observationer visar på vilka slag av samtal som kan förekomma. Det är inte alla som gäller eller leder fram till bokning av tid för ansökan om ekonomisk hjälp. Under en månad fick socialsekreteraren enligt den statistik han fört ta emot 95 samtal. Av dessa fick 61 nybesökstid. De övriga 34 samtalen har socialsekreteraren antingen hänvisat vidare till annan grupp inom organisationen eller till annan myndighet, t.ex till länsstyrelsen för överklagan eller till

8 "Information om socialbidrag"; förutom uppgifter om vad den sökande skall ta med sig, uppgifter som socialsekreteraren kryssar för under samtalet, finns också information om vad socialbidrag är, vad socialbidraget skall räcka till, aktuella belopp för socialbidrag per månad, vilka krav som ställs på den sökande, information om sekretess, socialregister och personakt mm. Broschyren omfattar 12 st A5-sidor: När det gäller vad den sökande skall ta med sig vid nybesöket finns 19 olika alternativ förtryckta samt en punkt övrigt. annat socialkontor. En del samtal har betraktats som rådgivning t.ex att man föreslagits ta kontakt med BUP eller med god man och slutligen har några kategoriserats som wannatı. Även här rör det sig om samtal som inte lett till någon fortsatt kontakt med socialbyrån. Tidigare studier, bl.a Cedersund (1992), visar också på att vissa samtal avslutas redan vid den första telefonkontakten genom att man hänvisar till annan myndighet då ärendet inte faller inom socialtjänstens ansvarsområde eller att man föreslår annan lösning. Av de 114 telefonsamtal som ingår i min observationsstudie erhöll 83 en nybesökstid, 31 hänvisades till annan myndighet eller föreslogs annan lösning. Samtliga fyra personer som beställde tid genom personligt besök erhöll en sådan.

\section{Sortering, kategorisering och etikettering}

Socialsekreteraren i tidsbeställningen har till uppgift att göra en första sortering av dem som ringer. Skall de slussas vidare in i organisationen och i så fall vart? Skall de hänvisas till annan myndighet, alltså har de ringt till "rätt" instans eller är de kanske inte alls berättigade till någon form av ekonomisk hjälp? Socialsekreteraren i tidsbeställningen fungerar alltså som en slags "gatekeeper" (grind- eller dörrvakt)' dvs. han avgör vem som släpps in på socialkontoret, vem det är som får tillträde och vart eller till vem man kommer. ${ }^{9}$ Den ovan redovisade statistiken visar att ca två-tredjedelar av samtalen leder till att en nybesökstid erhål-

9 "Gate-keeper" är ett begrepp som ursprungligen använts av Kurt Lewin; Psychological Eco$\operatorname{logy}$ (1943) i Field Theory in Social Science -

Billquist - Byråkrati och pesonligt bemötande - studier av tidsbeställning 
les. Det är något fler samtal som blir föremål för åtgärd av socialsekreteraren än vad Cedersunds studie redovisat där ca hälften av samtalen inte ledde till några fortsatta åtgärder från socialsekreterarens sida. En anledning till att fler samtal åtgärdas i min studie kan vara att den socialsekreterare som ansvarar för tidsbeställningen inte per telefon kan avslå någon ansökan om ekonomisk hjälp. Alla har rätt att söka och att få sin ansökan prövad. Socialsekreteraren kan säga till den sökande att det är svårt att se att ni kan få hjälp men "ni kan alltid söka». Han kan här sägas använda sig av en avvaktande strategi dvs. i den bemärkelsen att den sökande får avgöra om han skall försöka få sin ansökan prövad eller ej (jfr Cedersund 1992 s 36). Skulle den sökande ligga över socialbidragsnormen kan man också hänvisas till andra instanser beroende på vad man berättat om sin situation, t.ex hänvisas till bank för att få mer förmånliga lån eller till familjerådgivning för att diskutera en ömsesidig underhållsskyldighet. Den sökande är välkommen att höra av sig på nytt. Det är få personer som direkt avvisas vid tidsbeställningen då dörren alltid lämnas öppen för att man skall kunna återkomma. Under mina observationer avvisades ingen medan en avvaktande strategi användes i relation till tre personer. ${ }^{10}$ Socialsekreteraren ser inte som sin uppgift att göra prövningen om den sökande är berättigad eller ej till ekono-

Selected Theoretical Papers (1951) . Begreppet har senare använts av Lipsky (1980), Cedersund (1992) m.fl. som studerat hur människor sorteras och hanteras i människovårdande organisationer.

10 Min närvaro vid tidsbeställningen skulle kunna påverka samtalens utformning, men då jag miskt bistånd och han menar att det inte per telefon går att göra en samlad biståndsbedömning då många ringer från sina arbetsplatser och »kan knappt med att prata». Andra saknar telefon och måste kanske ringa från affären eller någon annan offentlig telefon och åter andra har haft tidigare kontakt med socialtjänsten och känner till normerna och vad som gäller. Socialsekreteraren gör alltså inte så djupgående ekonomiska utredningar och beräkningar som fallet tycks vara i t.ex. Cedersunds studie eller som det blir då tidsbeställningen sker direkt hos den socialsekreterare som senare själv skall ta emot nybesöket. Jag kan här jämföra med observationerna av tidsbeställningssamtal från det andra socialkontoret där tidsbeställningen sker direkt hos den socialsekreterare som fortsättningsvis skall handlägga ärendet. Ytterligare en anledning till skillnaden $i$ antal sökande som erhåller nybesökstid mellan min och Cedersunds studie skulle kunna vara att socialsekreteraren i tidsbeställningen inte själv tar emot nybesök.

Om den som ringer är i åldern 18-25 år får han nybesökstid hos någon av socialsekreterarna i ungdomsgruppen. Är den som ringer flykting och inte har bott fem år i Sverige eller är gift med svensk medborgare får sökande tid hos flyktinggruppen. Övriga får tid hos gruppen för social rehabilitering. Inom grupperna är det den första lediga besökstiden som styr när man kan komma.

\footnotetext{
deltagit under så pass lång tid och vi diskuterat detta tror jag inte att min närvaro påverkat i någon större utsträckning då jag ofta "glömdes bort«. Skillnaden mellan min studie och Cedersunds kan inte heller förklaras med detta då vi båda närvarit vid telefonsamtalen.
} 
Det är alltså ålder och flyktingstatus som utöver "första lediga tid" styr vart man kommer. Det finns inga andra "sorteringskriterierı. Väntetiden kan variera mellan grupperna och från tid till annan. Under min observationsperiod, som pågick under sju månader, varierade väntetiden mellan en till fem veckor. Är det ett akut behov av ekonomisk hjälp får sökande dels en nybesökstid men också en hänvisning till den socialsekreterare som har jouren. Av samtalet måste det framgå att behovet är akut. I vissa samtal kan socialsekreteraren, t.ex. om det är lång väntetid och sökande reagerar på detta eller om det av samtalet i övrigt framgår att den sökande har en pressad situation, säga att »klarar du dig inte så ringer du vår jour "eller "har du inte mat för dig och ditt barn fär du ringa jouren«. De uppmanas också när de kontaktar jouren uppge att de fått en nybesökstid.

En första kategorisering av den sökande sker under telefonsamtalet. På blanketten "nybesök - checklista och statistik" skrivs, förutom den sökandes och medsökandes personuppgifter, också ned kortfattad information till kommande handläggare. Och det kan vara information som anger att den sökande är sjukpensionär, arbetslös, saknar Akassa eller att det kanske rör sig om en »rörig ekonomi . Socialsekreteraren anger också om sökanden tidigare varit aktuell, om den sökande är nyanländ flykting och i så fall ankomst till Sverige och anknytning till området. Information som socialsekreteraren frågat efter under det inledande samtalet. På „checklistan» kan socialsekreteraren ibland ge "signaler" till den kommande handläggaren för att denne skall få en uppfattning om att det inte bara rör en ansökan om ekonomisk hjälp. Signaler som kan ses som ett rudimentärt försök att göra en form av probleminventering som skulle kunna föregå den byråkratiska processen (Bernler/ Johnsson 1995). Exempel på sådana signaler kan vara; relationsproblem, vill flytta, nyligen frånskild eller separerat. Blanketten lämnas sedan till den handläggare som den sökande erhållit tid hos. Samtidigt rekvireras eventuell tidigare socialakt från socialregistret.

Det första steget i en klientiseringsprocess har tagits. Själva klientkonstruktionen består av två huvudmoment: "först måste individen standardiseras (kan vara berättigad till ekonomiskt bistånd, min kommentar) dvs. reduceras till de variabler som faller innanför organisationens specialiseringsområde, och sedan måste han kategoriseras (i första hand ålder, flyktingstatus och därefter arbetslös, sjukpensionerad $\mathrm{mm}$, min kommentar) vilket innebär att hans standardiserade egenskaper matchas mot organisationens uppdragna gränser så att man hittar en passande administrativ kategori att placera honom i. (Johansson 1992 s 56). "Signalerna» som ges av socialsekreteraren kan ses som ett försök att inte bara placera den sökande i en administrativ kategori utan att kvarhålla något av det personliga i situationen, att inte helt och hållet ge henne en "byråkratisk identitet" (a.a 1992).

\section{Samtalet-dess innehail, uppläggning och struktur}

"Tidsbeställningen, (namn) ... hej ... Vad gäller det? Är det ekonomiska problem? ... Ar det län och så? ... jag skriver räkningar ... jobbar du? ... sjukpensionerad ... kan jag få ditt personnum- 
mer ... ditt personnummer, det här var ditt telefonnummer ... (knappar in på datorn, skriver namn) vad kallas du för? ... första tid är den 13 februari klockan tio ... ja, två veckor ... vi är i $A$ torp vid torget ... nu vet jag inte hur handikappad du är, åker du buss?... färdtjänst (sedan förklarar socialsekreteraren var socialkontoret ligger, hur hon skall ta sig in med hjälp av dörröppnare och hiss, han berättar att det kan bli lite besvärligt uppe vid receptionen men att hon kan be om hjälp, han berättar också att han fyller i en lapp till henne som han skickar hem) ... är det så att du har mycket räkningar ta med dom ... så är du välkommen dåu (citat från observation av tidsbeställning).

De tidsbeställningssamtal som jag har observerat kan inte sägas ha en sådan "fast" struktur som anges av Cedersund utan en större variation förekommer. Samtalen har snarare, som Bernler/Johnsson säger, »en fri form men där det finns en bakomliggande struktur" (1995 s 91). Efter den inledande hälsningsfrasen kan socialsekreteraren antingen ställa en fråga om vad det gäller eller lyssna ganska länge till den sökandes egen berättelse och presentation av sitt ärende. Han kan under denna berättelse ställa utredande frågor men också göra kommentarer av olika slag. Han lyssnar när detta känns angeläget och nödvändigt. Även om det $\mathrm{i}$ samtalen finns en röd tråd som innebär att få en bild över vad den sökande behöver hjälp med, om denna hjälp kan ges inom socialkontoret eller om socialsekreteraren på annat sätt kan vara behjälplig är det ingen mall som följs. Småsnack vävs in för att underlätta samtalet och skämt förekommer gärna. Samtalen ger ofta ett lättsamt intryck. Innehållet varierar beroende på den sökandes situation men de flesta samtalen handlar om den sökandes ekonomiska si- tuation även om det inte är några detaljerade ekonomiska beräkningar som görs.

Socialsekreteraren menar att det är viktigt att människor skall känna att det inte är svårt att ringa hit och ta kontakt. Man skall inte känna sig som "socialfall«. Ett bra bemötande är viktigt men det är också viktigt, menar han, att inte lova något, watt inte inge förhoppningar». Oftast ganska tidigt i samtalet, många gånger innan utredande frågor ställs, efterfrågas den sökandes personnummer. Dock har socialsekreteraren fått en bild av vad ärendet gäller, för i ärenden som t.ex. hänvisas till annan myndighet efterfrågas i de flesta fall ej personuppgifter, åtminstone dokumenteras de inte.

Personuppgiftsfasen kommer alltså i många fall betydligt tidigare, vilket den också gör i de av mig observerade samtalen på det andra socialkontoret, än i de av Cedersund refererade och analyserade samtalen. Personnumret knappas in på datorn för att kontrollera att den sökande tillhör socialkontorets upptagningsområde. Socialsekreteraren frågar då också efter den sökandes adress och tilltalsnamn; en slags dubbelkontroll eftersom adressen framgår av datorn. Han förklarar inte varför han frågar om personnummer eller att han kollar via kommunregistret. Detta förklarar han enbart om någon frågar och, uppger han, det är inte ofta eftersom man idag är van vid att både uppge sitt personnummer och vid datorer. Däremot säger han många gånger i och under samtalen att han skriver och varför. Han refererar också för den sökande vad han skrivit t.ex. ijag skriver här en rörig ekonomi, det var det du sau. Socialsekreteraren kan också via datorn se om den sökan- 
de tidigare varit aktuell på byrån samtidigt som han också ställer denna fråga.

Den sökande får därefter besked om vem hon fått tid hos och när. Ibland, men ytterst sällan, kan den sökande få tid hos den socialsekreterare som hon eventuellt tidigare haft kontakt med. Då måste denna socialsekreterare ha den första lediga tiden och inget av de andra sorteringskriterierna, ålder och flyktingstatus, får ha ändrats. Ibland kan det bli diskussion om att det är lång väntetid eller att tiden av andra anledningar inte passar den sökande. Det är inte många samtal som jag lyssnat till där man inte har nöjt sig med den föreslagna tiden. Kanske är det många som resonerar som några av de intervjuade klienterna gjorde att "det hjälper inte om man slär på dörren " eller man får ta "i tur och ordning". Kanske är det så att man inte vill bråka, man vill inte ge en negativ bild av sig själv för risken att det senare skall påverka ens möjligheter till att få hjälp. Man formar sig efter organisationens krav (jfr Schwartz 1975, Lipsky 1980, Nilsson 1989).

Samtalen avslutas med att den sökande får veta vad hon skall ta med sig av uppgifter till nybesöket, att en ansökningsblankett skickas hem, en påminnelse om tiden för besöket ges och ett avslutande "då är $d u$ välkommen« sägs.

\section{Klienternas upplevelser}

\section{Skam och skuld}

Redan innan kontakt tagits med socialbyrån finns hos de sökande föreställningar och förväntningar om problemet, om den andre och om hjälpen (Bernler/Johnsson 1988, 1993). Vad man vill ha hjälp med och hur man ser på problemet styr ofta vart man vänder sig. Föreställningarna om socialbyrån och att ansöka om socialbidrag präglas ofta av hörsägner och generaliseringar. I vårt samhälle finns ganska utbredda uppfattningar, trots att de är dåligt underbyggda, om att människor många gånger oberättigat utnyttjar socialbidraget och att den som får ekonomisk hjälp ofta själv bär skulden till att han inte klarar sig ekonomiskt. Dessa uppfattningar är fördomsfulla och starkt moraliserande och finns kanske framför allt hos dem som aldrig har behövt vända sig till socialbyrån. Denna mytbildning leder bl.a. till en motvilja hos många att ansöka om hjälp. Ett motstånd måste övervinnas och detta winnebär också alltid ett personligt nederlag" (Nilsson 1989 s 31).

Att leva på socialbidrag eller på arbetslöshetsunderstöd kan nedvärderas av människor och det kan kännas skamligt att man inte själv har tjänat ihop till sitt levebröd (Starrin, Rantakeisu, Hagquist 1996). Att behöva gå till socialkontoret och begära hjälp innebär alltså för många människor känslor av skam och skuld. Det är känslor som man inte heller befrias ifrån efter första besöket på socialbyrån (Socialstyrelsen 1987, 1990, Nilsson 1989). Dessa känslor upplevs redan innan man kontaktar socialbyrån och man drar sig i det längsta för att ringa. Till detta kan också läggas att då den första kontakten oftast sker via telefonsamtal känner man sig än mer wutlämnad" (Ahrne 1987). Men, menar en av de intervjuade i min studie, "har man inget arbete så har man inte". För många finns minget alternativ" och det är »enda utvägen«. En av de intervjuade, en arbetslös kvinna, menar att hon var tvungen att gå dit, att hon 
helst skulle vilja ha sluppit det »det känns som man är $i$ fängelse" och hon liksom fler av de intervjuade poängterar att de vill klara sig själva. Brist på andra möjliga alternativ gör att man söker hjälp. Även om människor vet att socialbidrag är en rättighet upplever man det inte så utan man känner sig många gånger stämplad som personligt misslyckad och då oftast oavsett orsak till behovet av hjälp (Socialstyrelsen 1990). Känslor av obehag, skuld och skam finns hos de flesta och detta har många spontant uppgivit, ibland innan jag ens har hunnit fråga dem om deras upplevelser;

»... inte stolt för att jag behövde kontakta dom ... känns otäckt ... förnedrande ... det är medblandade känslor.. men alla säger att det inte är som på trettiotalet « (ensamstående kvinna, 70 år)

"Det känns ej bra att komma hit ... det känns tungt" (ensamstående kvinna med barn, invandrare)

"Om det var pinsamt menar du? " (ensamstående kvinna, 24 år)

"... men känslan av att bli avklädd" (ensamstående kvinna, 40-års åldern)

"Det är inget man vill ... man måste ... vill inte leva på föräldrarna längre" (ensamstående man, 19 år)

1... rätt obehagligt trots att man vet att det är ens rättigheter"(ensamstående kvinna, 57 år)

"... det är inte varje månad (som man tar kontakt) "(ensamstående kvinna, pensionär)

"Jaa, det är alltid motigt att ringa dom ... man har hört att många säger att det är nej" (gift kvinna)
"Gå till det sociala bär emot" och han menar att "gå till socialen är det sista man gör (ensamstående man, 50-årsåldern)

Många oroar sig också för vad som kommer att hända, vem kommer man att möta och kommer man att bli förstådd. Man tycker det är obehagligt och känner sig nervös och kommer man då att kunna, som en av de intervjuade sa, "få fram det man vill ha sagt? ". Eller som en annan av de intervjuade menade, att hon skämdes inte för att kontakta socialbyrån men hon oroade sig för om hon skulle bli förstådd. Skulle hon möta någon som lyssnade på henne och inte bara gjorde ekonomiska beräkningar eller? Hon påverkades mycket av sina tidigare erfarenheter från kontakt med socialtjänsten och hon önskade sig mer mänskliga och lyhörda personer.

\section{Tillgänglighet}

Det kan inte alltid vara så lätt att veta vart och när man ska ringa. De sökande har antingen tittat i telefonkatalogen, pratat med vänner eller fått hjälp från tidigare kontakter inom socialtjänsten för att veta vart de skall vända sig. "Det var inte lätt" säger en av mina intervjupersoner. "... men du kan inte ringa idag, du får vänta tills på måndag" var ett besked som gavs i telefonväxeln till den person som råkade ringa på "fel« tid, då tidsbeställning endast sker på särskilda dagar och tider. Att det kan vara svårt att komma rätt kan ytterligare en av intervjupersonerna vittna om som uppgav att de i växeln frågat honom om det var akut och i så fall kunde han återkomma om fem minuter. Detta kunde han inte utan återkom nästa dag och då fick han beskedet att han skulle tala 
med tidsbeställningen. Ingen hade nämnt detta vid första påringningen dvs. att det fanns en speciell tidsbeställning och han kände sig förvirrad. En annan av de intervjuade menar satt de inte så ofta är trevliga $i$ telefonväxeln « men att detta gäller för alla "växlar" för det är så många som ringer. De som haft tidigare kontakt med detta socialkontor vet däremot hur de skall göra och vad de skall säga i växeln. ${ }^{11}$ För dem tycks det inte vara några svårigheter utöver att det kan vara svårt då tidsbeställningen bara kan göras vissa dagar och tider. Det verkar som de will inte att man skall ringa". En menade att det var inte svårt att komma fram till tidsbeställningen däremot kan det vara svårt att komma fram till socialsekreterarna då de bara har en timmas telefontid på morgonen. Uttalanden som visar på den maktlöshet som kan kännas i kontakten med byråkratin och dess svårigheter att kunna ge klara besked. En maktlöshet som väcker irritation (Ahrne 1987).

Att svårtillgängligheten är stor när det gäller att nå fram till socialkontoret eller till socialsekreterarna visar även andra studier över socialbyråarbetet (Marklund/Nordenstam/Penton 1984, Socialstyrelsen 1987). I Perzons och Wickströms studie (1996) säger klienterna att de inte hade räknat med att det skulle vara så svårt att nå fram varken till växeln eller sedan därifrån till tidbokningen. De hade ringt och ringt ibland i flera dagar innan de nått fram. Och de hade inte heller räknat med att väntetiden skulle

11 Någon mer ingående studie av hur samtalen behandlas i telefonväxeln har inte gjorts utan bygger enbart på de intervjuer som jag gjort med de sökande. vara så lång som den ibland visade sig vara. En man i min studie uppger att han har väntat in i det längsta med att ringa. Han har hoppats på att arbetslöshetsersättningen skulle betalas ut, räkningarna har hopat sig och så får han vänta i två veckor då han trott att det skulle ta ett par dagar »nu var detta katastrofu. För merparten av de jag intervjuat har väntetiden rört sig om ca två veckor och de har inte nämnvärt reagerat över detta utan accepterat och menat att det nog är normalt med tanke på att det är många som söker. Man har med andra ord funnit sig i situationen (jfr Schwartz 1975).

\section{Bemötande och förväntningar}

Många har känt oro inför att ta den första kontakten med socialkontoret och man har väntat in i det längsta. Hur upplevs då samtalet, frågorna som ställs och bemötandet?

"Han frägade vad jag sökte för, vad jag hade $i$ pension och så..." (ensamstående kvinna, pensionär)

"Ganska okej, han ville ha reda på varför och det måste man förklara" (gift, kvinna)

"Det är inga svåra samtal, det är lätta saker" (man, 19år)

"Det var inget felı (man, 20 år)

"Han frägade varför jag ringde och jag svarade. Han var trevlig" (ensamstående kvinna, 24 år)

"För all del, inget otrevligt sades, men man hör den lilla tonen i rösten « som gör att man känner sig ... »mindre än den jag är"... »att han var stor men jag var liten«. Den intervjuade tar upp att känslan försvann på några sekunder och han var "Lennart", att han inte satt på någon hög 
stol utan att det kändes som ....Viär på samma nivå" och denna känsla gör att man vågar öppna sig och berätta det som är svårt (ensamstående kvinna, 40-års åldern)

"Han var mycket trevlig. Det hade jag inte väntat ... han pratade ju, det var som om jag var en människa på andra sidan luren" Det var mycket mera positivt än förväntat fast ....jag kanske har förutfattade meningar " (ensamstående kvinna, 70 år)

\section{"Det var inget jobbigt samtal" (gift kvinna)}

"Han va lábra. Han var väldigt trevlig... ibland kan de vara lite snorkiga men det var inte han" (ensamstående kvinna, 57 år)

"Han ställde inte så många frågor, han frägade ompersonnummer och adress ... en bra kontakt" (ensamstående kvinna, 40 års åldern)

"... han sa inte så mycket, han skrev mest och slog pả sin dator... letade väl efter bokstäverna, han var upptagen ... han var trevlig så. ... Han ville bara ha uppgifter om vem jag var" (man, 50-års åldern)

"Han var väldigt trevlig" ... "jobbigt överhuvudtaget, att man måste berätta om sitt privata liv" (gift, kvinna)

Ytterligare någon person bland de intervjuade uppger att socialsekreteraren var trevlig, någon att han var lugn och sansad och att wi skojade med varandra". De flesta upplever att de blivit vänligt bemötta och några är förvånade över detta då man inte förväntat sig det. Här kan den s.k. „Tack bra effekten" ha påverkat intervjusvaren då, vilket andra undersökningar funnit (Socialstyrelsen 1987), klienter många gånger tenderar att svara positivt på allmänt formulerade frågor. Men av svaren som helhet framgår att de känner sig väl bemötta vid tidsbeställningen och att de inte heller har uppfattat de frågor som ställdes som konstiga eller kränkande utan det är sådana frågor som, menar de, måste ställas även om en kvinna tycker det är jobbigt att man måste berätta om sitt privatliv. En kommentar som bottnar i tidigare erfarenheter och som inte bara gäller tidsbeställningen utan också det kommande besöket och överhuvudtaget kontakten med socialbyrån.

De som har ringt har förväntat sig att de skall få en tid för att kunna göra sin ansökan om ekonomiskt bidrag eller som en av de intervjuade sa att hon förväntade sig att få en tid för att netablera en kontaktu. Man har inte förväntat sig att bli nekad en tid. En uppger att hon hade väntat sig att få prata med den socialsekreterare som hon skulle gå till men "det gick väl bra detta medu. Vid min intervju framkommer att några oroar sig för det kommande besöket och undrar över hur de skall bli bemötta där och en uttrycker sig så här »hur bli den andre jag skall träffa? Når jag honom, àtminstone till hälften? «. Hon skulle gärna ha velat träffa den person som tog emot $\mathrm{i}$ tidsbeställningen eller som hon uttrycker det "personen med den rösten«. Det är jobbigt att berätta "för en till, att dra allt från början «. Även av mina observationer har jag förstått att en del av de sökande har förväntat sig att få fortsätta kontakten med socialsekreteraren i tidsbeställningen. Man har samlat kraft för att ringa, känner att man blivit bra bemött och så skall man träffa ytterligare en ny person vilket kan kännas svårt för en del. Det är inte alltid som klienterna upplever socialkontorets uppstyckning av sin verksamhet i olika funktioner som positiv. 


\section{Sammanfattning}

Människors första kontakt med socialtjänsten sker oftast via telefon åtminstone när det gäller att ansöka om ekonomisk hjälp. Ett samtal där man möter en tjänsteman, oftast socialsekreterare, som har till uppgift att göra en första sållning och sortering av de sökande enligt krav som organisationen, i detta fall socialbyrån, har ställt upp. Ett samtal där risken är stor att den sökande kommer att uppleva att hon "behandlas som ett nummer av byråkratin" (Johansson 1992 s 36), att hon reduceras till att passas in i det regelsystem som organisationen har satt upp och att hon erhåller en "byråkratisk identitet“ (a.a s 52). Ett första samtal som för en del av dem som slussas vidare in i organisationen innebär ett första steg in i ett klientskap.

Många som ringer har väntat in i det längsta och kontakten präglas av känslor av skuld och skam och av en oro för hur man kommer att bli bemött. Kommer man att bli förstådd? Kommer man att erhålla tid för ett personligt besök? Kommer man att få hjälp? Samtidigt som socialsekreteraren i tidsbeställningen skall undersöka att de sökande uppfyller organisationens krav och kriterier, dvs. avgöra om den sökande har rätt till en inträdesbiljett, skall han också bemöta människor som kanske befinner sig $i$ kris eller för vilka det varit ett stort steg att ta kontakt med en socialbyrå. Att bli avsnäst eller behandlad med oförstående, att känna att man inte blir trodd kan få negativa kon- sekvenser för en person som redan kan ha känslor av ett personligt nederlag (jfr Arntsberg 1989).

Avsikten med min artikel har varit att lyfta fram dessa initiala samtals betydelse för klienten och för vägen in i ett klientskap. Hur man bemöts och hur den "första rösten" upplevs i kontakten med socialtjänsten har stor betydelse för den enskilde sökanden och det har också en betydelse för hur en eventuellt fortsatt kontakt med socialtjänstens tjänstemän fortlöper och upplevs. I dessa samtal sker en första kategorisering av de sökande efter kriterier som organisationen angivit och den process påbörjas där den sökande omvandlas till klient. Samtalen har en byråkratisk ram med en bakomliggande struktur. Inom denna ram kan samtalen varieras och även andra foci än de rent byråkratiska kan urskiljas, t.ex. vidare probleminventering. De sökandes negativa förväntningar inför det första "mötet», deras förväntan att få möta en "byråkrat», kan förändras till det positiva genom samtalet och det bemötande de får. Genom att bli hyggligt och personligt bemött i tidsbeställningen, genom att uppleva att någon lyssnar och att man inte helt reduceras till en administrativ kategori kan de sökande lyckas övervinna en del av sin oro och sina känslor av skuld och skam. Det initiala samtalet får betydelse för hur klienten upplever sitt klientskap, men naturligtvis är detta bara ett i raden av flera samtal med socialtjänstens tjänstemän. 


\section{Referenser}

Ahrne, G(1987) „Byråkrati i organisationer och samhälle» i Bergryd, U (red.) Den sociologiska fantasin-teorier om samhället. Simrishamn: Raben \& Sjögren

Arntsberg, K-O (1989) Socialarbetare. Lund: Studentlitteratur

Bernler G, Bjerkman A, Bäck-Wiklund M, Johnsson L \& Olsson S (1989) Vägar till och frän klientskapet. Forskningsprogram för en forskargrupp vid institutionen för socialt arbete, Göteborgs universitet. Göteborg: Institutionen för socialt arbete, Göteborgs universitet

Bernler, G\& Johnsson, L (1988) Teori för psykosocialt arbete. Stockholm: Natur och Kultur

Bernler G, Johnsson L \& Skårner A (1993) Behandlingens villkor. Om relationen och förväntningarna i det sociala arbetet. Stockholm: Natur och Kultur

Bernler, G \& Johnsson, L(1995) Den sociala journalen II: Tre bilder av socialtjänstens klienter. Rapport 1995:7. Göteborg: Institutionen för socialt arbete, Göteborgs universitet

Cedersund, E (1992) Frän personligt problem till administrativt beslut. Att ansöka om ekonomiskt bistånd. SIC 33, Linköping: Studies in Communication, University of Linköping,

Erickson, F \& Schultz, J (1982) The Counselor as Gatekeeper - Social Interactions in Interviews. New York: Academic Press

Fredin, E(1993) Dialogen i socialt arbete. SIC 36. Linköping: Studies in Communication, University of Linköping

Hasenfeldt, Y (1983) Human Service Organisations. Michigan: University of Michigan

Henriksson, B \& Månsson, S-A (1996) "Deltagande observation" i Svensson, P-G \& Starrin, B Kvalitativa studier i teori och praktik, Lund: Studentlitteratur

Hopper, R (1989) Speech in Telephone Openings: Emergent Interaction v. Routines. Western Journal of Speech Communication, 53, 178-194

Hydén, L-C (1988) Fredagsarbetet Scener frain en socialvårdsbyrå. Rapport nr 82 (stencilupplaga). Stockholm: Stockholms socialförvaltning, Forsk- nings- och utvecklingsbyrån, Socialt arbete Johansson, R (1992) Vid byråkratins gränser, Om handlingsfrihetens organisatoriska begränsningar $i$ klientrelaterat arbete. Lund: Arkiv avhandlingsserie

Kullberg, C (1994) Socialt arbete som kommunikativ praktik. Samtal med och om klienter. Linköping: Tema kommunikation, Linköpings universitet

Lewin, K(1951) „Psychological Ecology“ (1943, orginalutg). Cartwright, D (ed.) Field Theory in Social Science-Selected Theoretical Papers. New York: Harper \& Brothers

Linell, P (1990) De institutionaliserade samtalens elementära former: om möten mellan professionella och lekmän. Forskning om utbildning 4, 18 $-35$

Lipsky, M (1980) Street-level bureaucracy. Dilemmas of the individual in public services. New York: Russel Sage Foundation

Marklund S, Nordenstam K \& Penton R (1984). Socialvärlden-Om mötet mellan socialarbetare och klient. Stockholm: Liber förlag

Nilsson, G(1989) Fattigliv. Meddelande från Socialhögskolan 1989:1, Lund: Socialhögskolan, Lunds universitet

Perzon, A \& Wickström, M(1996) SocialkontoretVar god vänta! Långa väntetider för nybesökvad innebär det för socialsekreterare och klient? C-uppsats i socialt arbete 1996, Göteborg: Institutionen för socialt arbete, Göteborgs universitet

Prottas, J (1979) People-processing. The street-level bureaucrat in public service bureaucracies. Lexington: Lexington Books

Ranger, M (1986) „Er det bare meg som roter sän?" Klientsamtaler på ett sosialkontor. Oslo: Universitetsforlaget

Salonen, T (1993) Margins of Welfare - A study of modern functions of social assistance; Kristianstad: Hällestad Press

Sarangi, S \& Slembrouck, S(1996) Language, Bureaucracy and Social Control. London and New York: Longman 
Schwartz, B (1975) Queuing and Waiting - Studies in the Social Organizations of Access and Delay. Chicago and London: University of Chicago Press

Socialstyrelsen (1987) Vad tycker klienterna? PM 171/87. Stockholm: Socialstyrelsen

Socialstyrelsen (1990) Behövs socialbyrån? Socialbyråprojektet. SoS-rapport 1990:27. Stockholm: Socialstyrelsen

Starrin B, Rantakeisu U \& Hagquist C (1996) Om arbetslöshetens ekonomi och skam. Socialvetenskaplig tidskrift 3: 1-2, 91-115

Sunesson, S (1981) När man inte lyckas. Om hinder, vanmakt och oförmåga i socialt arbete. Lund: Liber förlag

Sunesson, S (1985) Ändra allt! En uppmaning till socialarbetare. Lund: Liber förlag

Whalen J, Zimmerman D \& Whalen M (1988) When Words Fail: A Single Case Analysis. Social Problems Vol 35, No 4, 335-362

\section{Summary \\ Bureaucracy and reception of the individual - a study of the initial telephone call in which an appointment to apply for financial assistance is arranged}

The initial contact between citizens and the social welfare office is mostly done by the telephone, at least when it is about an application for financial assistance. This first meeting is a conversation where the social worker acts as a "gate-keeper". He has to sort out the applicants according to criteria set by the organization. He has to decide whether the person will get an admission ticket or not. In this conversation there is a risk that the applicant will feel that she and her problems will be reduced to fit the rules of the organization and that she receives a bureaucratic identity.

This study emphasizes the importance of this first conversation for the client and her way into clientship. The study shows that during the first call, there is a categorization of the client according to the rules made by the organization. The process begins when the person is transformed to a client. The result indicates that this first conversation has a bureaucratic frame with an underlying structure but the conversation can, within this frame, vary and other foci than the bureaucratic can be seen: for example further inventory of problems. Most of the applicants in the study expect to meet a bureaucrat but these expectations can change into the opposite by the conversation and the treatment they receive. Through kind and individual treatment, when they feel that somebody is listening and that they are not reduced to an administrative category the applicants can overcome some of their anxiety and their feelings of shame and guilt.

The study is based on the observations of 114 telephone conversations between applicants and one social worker that took place at a social welfare office in Göteborg. The conversation is documented by written notes. The data also consists of interviews (with 12 applicants that received an appointment) and of statistics. 